\section{Karakteristik Bangkitan \\ Lalu Lintas dan Pola Pergerakan pada Kawasan Perumahan}

Buku Karekteristik Bangkitan Lalu lintas dan Pola Pergerakan Pada Kawasan Perumahan ,bukanlah hal yang baru namun kehadiran buku ini dapat menambah khasanah ilmu sub bidang manajemen dan rekayasa transportasi. Hasil kajian dan penelitian ini mengilustrasikan bagaimana komparasi antara teoriteori terdahulu oleh para pakar (ilmu transportasi dan statistic program yakni SPSS), dan praktek (observasi, pengukuran, survey dan pencacahan lanjut) dapat menjawab sebagian analisis dan prediksi kedepan. Diharapakan dengan adanya buku ini penulis dapat mengembangkan limu pengetahuan serupa kedepan berupa penelitian-penelitian sejenis secara aplikatif serta terukur dan secara umum pembaca mendapatkan refrensi dan informasi yang di dapat. Untuk itu kritik dan saranyang konstruktif saya tunggu...

Penulis, Ir.Fery Hendi Jaya,5.T.,M.T.,IPP.

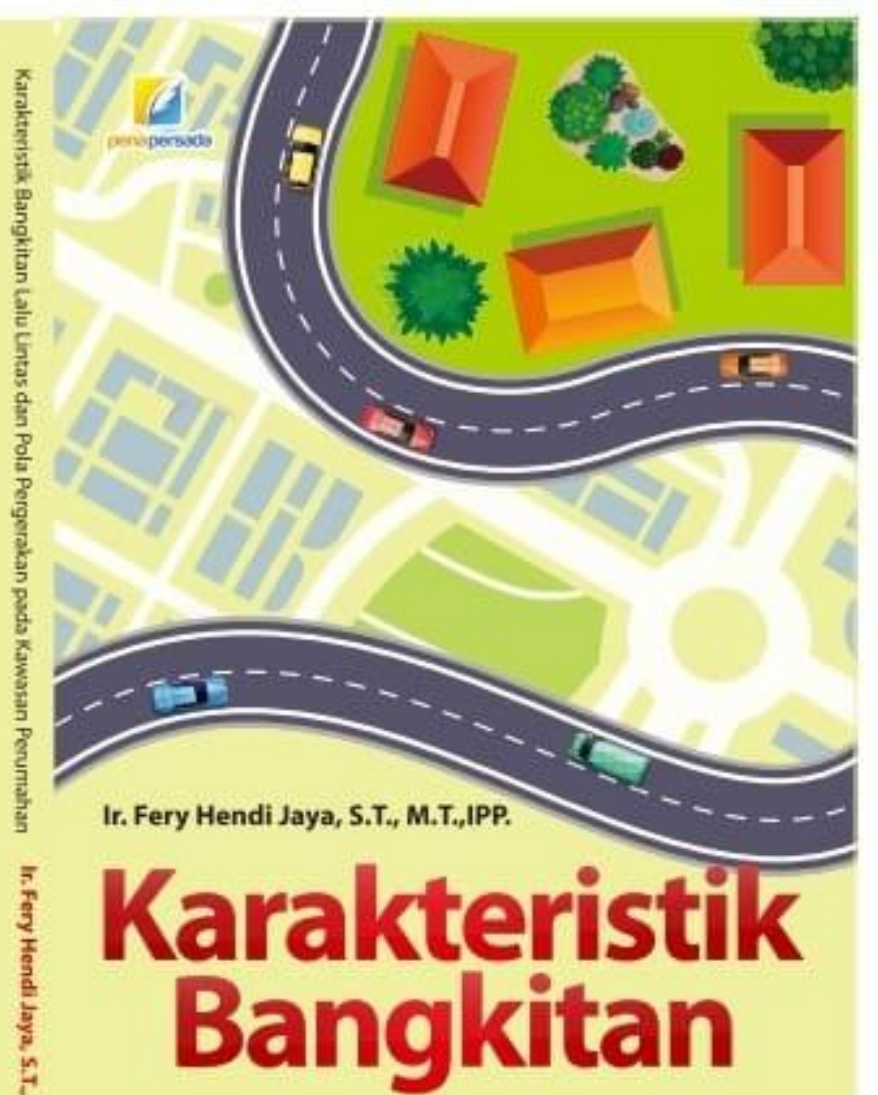

Lalu Lintas dan Pola Pergerakan pada Kawasan Perumahan 


\section{KARAKTERISTIK BANGKITAN \\ LALU LINTAS DAN POLA PERGERAKAN \\ PADA KAWASAN PERUMAHAN}

Ir. Fery Hendi Jaya, S.T., M.T.

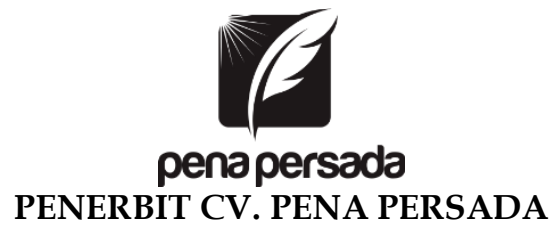




\section{KARAKTERISTIK BANGKITAN \\ LALU LINTAS DAN POLA PERGERAKAN PADA KAWASAN \\ PERUMAHAN}

\section{Penulis:}

Ir. Fery Hendi Jaya, S.T., M.T.

\section{Editor:}

Ir. Anwar, S.T., M.T.

Cahya Sujatmiko, S.T., M.T.

M. Fikri Akbar, S.I.Kom., M.Si., M.M.

ISBN : 978-623-6504-78-9

\section{Cover Design:}

Retnani Nur Briliant

Layout :

Nisa Falahia

\section{Penerbit CV. Pena Persada \\ Redaksi :}

Jl. Gerilya No. 292 Purwokerto Selatan, Kab. Banyumas

Jawa Tengah

Email : penerbit.penapersada@gmail.com

Website : penapersada.com

Phone : (0281) 7771388

Anggota IKAPI

All right reserved

Cetakan pertama : 2020

Hak Cipta dilindungi oleh undang-undang. Dilarang memperbanyak karya tulis ini dalam bentuk apapun tanpa izin penerbit. 


\section{KATA PENGANTAR}

Alhamdulillah, segala puji dan syukur kehadirat Allah SWT, serta shalawat dan salam penulis panjatkan kepada Nabi Besar Muhammad SAW, berkat ajaran beliau buku ini dapat tersusun.

Buku ini ditulis untuk membantu para mahasiswa dan praktisi dalam mempelajari dan mengembangkan konsep manajemen dan rekayasa transportasi pada bidang peminatan teknik sipil.

Isi buku ini juga disusun berdasarkan studi kasus serta datadata otentik pengamatan dilapangan yang bisa diproyeksikan sesuai dengan waktu, situasi, tempat dan kondisi sesuai kebutuhan.

Penulis menyadari dalam penyususnan buku ini jauh dari sempurna dan banyak kekurangan, namun penulis meyakini bahwa dapat bermanfaat bagi kita semua.

Akhir kata, kritik dan saran yang bersifat konstruktif dari pembaca sangat dinantikan guna penyempurnaan buku serupa kedepan.

Bandar Lampung, Februari 2020

Penulis 


\section{DAFTAR ISI}

KATA PENGANTAR .......................................................... iii

DAFTAR ISI ................................................................ iv

BAB I PENDAHULUAN ................................................ 1

BAB II MODEL BANGKITAN LALU LINTAS ..................... 4

A. Bangkit Lalulintas ................................................... 5

B. Tingkat Bangkitan Lalulintas .................................... 6

C. Model Bangkitan Pergerakan...................................... 7

D. Jenis Tata Guna Lahan.............................................. 8

E. Aktivitas Tata Guna Lahan ......................................... 8

F. Sebaran Pergerakan .................................................. 9

1. Pemisahan Ruang ................................................. 9

2. Intensitas Tata Guna Lahan .................................. 10

3. Pemisahan Ruang Dan Intensitas Tata Guna Lahan ........................................................... 10

G. Bangkitan dan Sebaran Pergerakan............................. 11

H. Klasifikasi Pergerakan .............................................. 11

I. Faktor Yang Mempengaruhi Pergerakan..................... 13

J. Fluktuasi Pergerakan ................................................ 13

K. Faktor Pemilihan Moda .............................................. 14

L. Jaringan Jalan............................................................... 14

M. Pengertian Transportasi ............................................. 16

N. Permasalahan Transportasi ........................................ 17

O. Perencanaan Transportasi .......................................... 18

BAB III METODOLOGI PENELITIAN ................................. 19

A. Umum ........................................................................... 19

B. Topik Penelitian .......................................................... 19

C. Survei Pendahuluan.................................................... 19

D. Survei Pustaka ......................................................... 20

E. Kebutuhan Data ..................................................... 20

F. Strategi Pengumpulan Data ........................................ 20

G. Analisis dan Pembahasan Data................................... 21

H. Penentuan Jumlah Sampel ........................................ 21

I. Pengujian Model Penelitian ....................................... 23

J. Hasil Uji Penelitian .................................................. 24 
BAB IV PENGUMPULAN DAN PENGOLAHAN DATA........ 26

A. Sketsa Umum Perumahan Way Kandis ....................... 26

B. Fluktuasi Lalu Lintas di Pintu Keluar Perumahan Way Kandis ................................................................. 26

C. Kerangka Sampel...................................................... 31

1. Identitas Kepala Keluarga .................................... 32

2. Identitas Jumlah Anggota Keluarga ....................... 32

3. Identitas Tingkat Pendidikan ................................ 33

4. Identitas Mata Pencaharian Penduduk .................... 34

BAB V ANALISA PENGARUH KARAKTERISTIK RUMAH TANGGA TERHADAP JUMLAH PERJALANAN .................. 39

A. Jumlah Kepala Keluarga Terhadap Jumlah Perjalanan

B. Jumlah Anggota Keluarga $>7$ Tahun Terhadap Jumlah Perjalanan..................................................... 39

C. Jumlah Anggota Keluarga Yang Bekerja Terhadap Jumlah Perjalanan

D. Jumlah Orang Yang Sekolah Terhadap Jumlah Perjalanan 40

E. Jumlah Pendapatan Keluarga Terhadap Jumlah Perjalanan. 41

Jumlah Kepemilikan Sepeda Motor Terhadap Jumlah Perjalanan.....

F. Jumlah Kepemilikan Mobil Terhadap Jumlah Perjalanan

BAB VI PENGUJIAN MENGGUNAKAN PERSAMAAN REGRENSI DAN ANALISA REGRENSI TUNGGAL ............. 43

A. Pengujian Menggunakan Persamaan Regrensi............ 43

B. Analisa Regresi Tunggal ............................................. 43

BAB VII ANALISA REGRENSI BERGANDA ....................... 50

BAB VIII PEMILIHAN MODEL BANGKITAN .................... 54

BAB IX PENUTUP ........................................................... 56

DAFTAR PUSTAKA .......................................................... 57

DAFTAR RIWAYAT HIDUP ............................................... 58 


\section{KARAKTERISTIK BANGKITAN LALU LINTAS DAN POLA PERGERAKAN PADA KAWASAN PERUMAHAN}




\section{BAB I PENDAHULUAN}

Prospektus pertambahan penduduk di wilayah perkotaan yang semakin pesat ini diakibatkan proses aktivitas manusia, beriringan dengan peningkatan usaha pemenuhan kebutuhan hidup mereka. Satu poin yang terpenting yakni mengenai pemukiman penduduk, Perumahan merupakan kebutuhan dasar yang harus dipenuhi disamping sandang dan pangan. Keterbatasan area kota terbagi dalam beberapa peruntukan seperti perumahan, perkantoran, industri, pendidikan, perdagangan jasa, tempat olahraga, wisata, sampai jalur hijau pelayanan kegiatan. Tapi kenyataannya lahan di kota tetap, walaupun jumlah penduduk terus bertambah dari tahun ke tahunnya.

Perkembangan kawasan perumahan yang berwawasan lingkungan dan nyaman merupakan salah satu faktor mendasar bagi kebutuhan masyarakat marjinal dan perlu mendapat perhatian khusus, karena lokasi lingkungan perumahan dalam struktur kota akan dapat mempengaruhi perkembangan dari kota tersebut. Pembangunan perumahan di kota-kota besar banyak dilakukan di pinggiran kota. Demikian pula di kota Bandar Lampung lokasi pembangunan perumahan diarahkan ke wilayah pinggiran kota ; di kecamatan Kemiling, Raja Basa, Sukarame dan Tanjung Seneng. Masalah perumahan yang bergeser kepinggiran kota diharapkan bukan sekedar menjadi suatu komunitas kelompok atau spoting masyarakat, tetapi menjadi transformasi kegiatan sosial, ekonomi dan budaya.

Kawasan komplek perumahan bila tidak memperhatikan penempatan tata ruang wilayah dapat menimbulkan model bangkitan lalu lintas yang dapat mempengaruhi keseimbangan transportasi pada jaringan jalan serta pola pergerakan penduduk disekitarnya. Persoalan transportasi yang muncul, disebabkan pertambahan penduduk kota, peningkatan kepemilikan kendaraan, peningkatan pendapatan penduduk yang diimplikasikan dibangunnya fasilitas perumahan. Apabila hal ini 
dikesampingkan akan mengakibatkan tingkat pelayanan menjadi rendah dan kemacetan. Kemacetan, secara ekonomi merupakan pemborosan bahan bakar, pembuangan emisi berlebihan mengakibatkan pencemaran lingkungan (polusi) dan rangkaian lain menimbulkan pelanggaran lalu lintas, menurunya etika berlalu lintas, dan tingginya angka kecelakaan.

Transportasi merupakan kebutuhan turunanderived demand akibat adanya aktifitas ekonomi,sosial, budaya dan sebagainya. Dalam kerangka makro ekonomi, transportasi merupakan tulang punggung perekonomian baik di tingkat nasional, regional maupun lokal, untuk wilayah perkotaan maupun pedesaan. Kota Padang sebagai ibu kota provinsi Sumatera Barat memiliki perkembangan yang pesat dalam kegiatan ekonomi, sosial, budaya dan kegiatan lainnya.Hal ini ditandai dengan aktivitas penduduk yang relatif tinggi seiring dengan kegiatan perjalanannya.Dengan demikian aktifitas yang terjadi akibat terbentuknya pusat-pusat kegiatan/tata guna lahan seperti pusat administrasi pemerintahan, pemukiman, sekolah, rumah sakit, fasilitas hiburan, dan pusat perbelanjaan. Hal tersebut menyebabkan bangkitan pergerakan yang begitu besar yang akibatnya berpengaruh terhadap sistim transportasi. Sekolah Menengah Pertama (SMP), Pertamanya tidak memiliki tempat/jalur khusus untuk menurunkan dan menaikkan penumpang. Hal tersebut menyebabkan kendaraan pengantar dan penjemput siswa berhenti atau parkir di daerah badan jalan, sehingga terjadi pengurangan kapasitas jalan. Akibatnya pada saat volume lalu lintas tinggi pada saat masuk sekolah dan pulang sekolah akan terjadi kemacetan lalu lintas. Kemacetan lalu lintas yang terjadi disaat jam masuk sekolah dan pulang sekolah. Bangkitan dan tarikan lalu lintas pada tata guna lahan khususnya pada kawasan pendidikan di Kota Padang merupakan salah satu permasalahan yang sering menyebabkan terjadinya kemacetan lalu lintas pada waktu sibuk pada pagi dan siang hari Untuk mengatasi permasalahan tersebut penulis memerlukaan suatu analisa bangkitan dan tarikan pergerakan arus 
lalu lintas. Dari hal tersebut cara mengatasi kemacetan tersebut dapat dilakukan dengan management lalu lintas.

Pada studi ini dan metode yang digunakan dalam menangani permasalahan serta perkembangan lebih lanjut dari kawasan perumahan begitupula meningkatkan pelayanan di bidang transportasi yang timbul, maka diperlukan penanganan khusus dengan mengetahui bangkitan lalu lintas dan prilaku pola pergerakan penduduk pada kawasan perumahan, berikut faktorfaktor yang timbul. Bangkitan lalu lintas dan pola pergerakan penduduk tergantung pada jumlah perjalanan yang terjadi dari suatu aktivitas orang yang memiliki kepentingan berbeda-beda. Karena sulitnya menghitung pergerakan atau perjalanan secara langsung, maka digunakan model pendekatan perhitungan yang dapat dinyatakan secara persamaan matematis (regresi linier). 


\section{BAB II \\ MODEL BANGKITAN LALULINTAS}

Bangkitan lalu lintas didefinisikan sebagai lalu lintas yang dibangkitkan suatu tempat (zona) dan menuju ketempat lain (zona). Zona didefinisikan sebagai suatu daerah kajian yang mempunyai pola tata guna lahan seragam. Suatu daerah kajian yang luas di bagi dalam beberapa zona yang pada umumnya dibatasi oleh batas-batas administrasi.

Prakiraan jumlah bangkitan lalu lintas akan menjadi pertimbangan yang penting dalam mendisain sistem transportasi di waktu yang akan datang. Tujuan dasar tahap bangkitan lalu lintas adalah menghasilkan suatu hubungan yang mengaitkan pola pergerakan dengan jumlah lalu lintas yang meninggalkan suatu zona. Tahapan bangkitan lalu lintas ini meramalkan jumlah perjalanan yang akan dilakukan oleh seseorang pada setiap zona asal dengan menggunakan data rinci mengenai tingkat bangkitan perjalanan, tingkat sosial ekonomi, serta tata guna lahan (TAMIN, 1997). Bangkitan lalu lintas adalah proses analisis yang menetapkan atau menghasilkan hubungan antara aktivitas kota dengan perjalanannya.
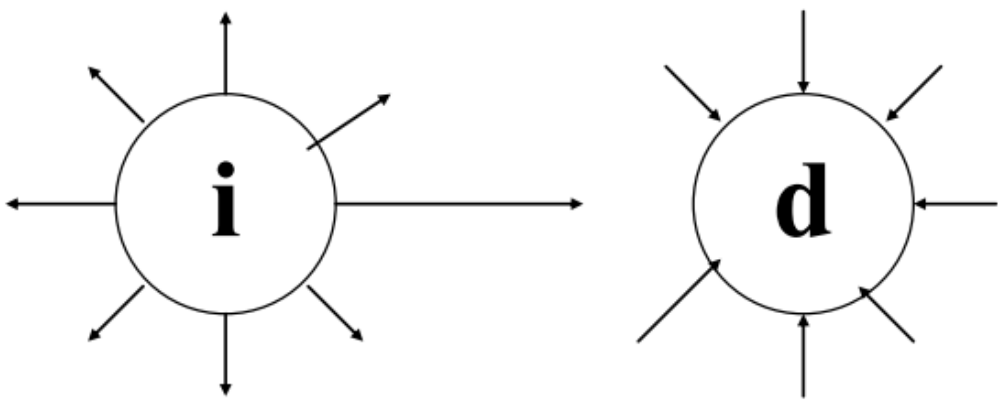

Gambar 1

Ilustrasi Bangkitan lalu lintas pergerakan dari suatu zona 
Perjalanan di bagi menjadi dua yaitu (WRIGHT, 1989):

1. Home based trip, Perjalanan yang berbasis rumah. Artinya perjalanan yang dilakukan berasal dari rumah dan kembali kerumah.

2. Non home based trip, Perjalanan berbasis bukan rumah. Artinya perjalanan yang asal dan tujuannya bukan rumah.

Pernyataan diatas menyatakan bahwa ada dua jenis zona yaitu zona yang menghasilkan perjalanan dan zona yang menarik suatu perjalanan, definisi "trip production" dan "trip attraction" adalah sebagai berikut:

a. Bangkitan perjalanan ('trip production) adalah suatu perjalanan yang mempunyai tempat asal dari kawasan perumahan di tata guna tanah tertentu.

b. Tarikan perjalanan ('trip attraction) adalah suatu perjalanan yang berakhir tidak pada kawasan perumahan tetapi pada tata guna lahan tertentu.

Untuk menghitung bangkitan pergerakan (perjalanan) dapat menggunakan model bangkitan pergerakan klasik. Model ini dipergunakan untuk memperkirakan pergerakan yang diproduksi (Oi) dan yang ditarik (Bd) setiap area zona, jumlah perjalanan yang berasal dari setiap zona, berdasar atribut sosial ekonomi pelaku perjalanan. Lebih lanjut perjalanan diklasifikasikan berdasarkan tujuan perjalanan, berdasarkan waktu, dan tipe orang berdasarkan tujuan meliputi tujuan bekerja, sekolah, belanja, sosial, dan rekreasi, perjalanan lain yang tidak rutin, yang bersifat home based. Dua perjalanan pertama merupakan perjalanan mutlak, sedangkan 3 berikutnya perjalanan opsional. Sedangkan untuk perjalanan non home based tidak dipisahkan karena hanya meliputi 15 \% sampai $20 \%$ dari total perjalanan (Ortuzar, 1994)

\section{A. Bangkitan lalulintas}

Analisis dampak lalulintas didasarkan pada suatu kondisi puncak yang menunjukkan dampak lalulintas terbesar. Kondisi puncak di wakili suatu bangkitan lalulintas per jam yang menimbulkan dampak terbesar. Kondisi sibuk lainnya dianggap mempunyai dampak lalulintas yang kecil, yang tidak 
perlu dianalisis lagi. Kondisi puncak dianggap terjadi pada salah satu kondisi berikut :

1. Kondisi lalaulintas sekitarnya pada jam sibuk;

2. Kondisi bangkitan lalulintas yang maksimum;

3. Kondisi sibuk khusus lainnya dianggap menentukan.

Dari ketiga kondisi tersebut dicari kondisi yang mempunyai kombinasi terbesar dari kondisi lalulintas sekitarnya ditambah dengan bangkitan lalulintas akibat pembangunan baru tersebut. Perhitungan bangkitan lalulintas perlu dilakukan pada jam sibuk sebagai berikut :

1. Jam sibuk pagi dari lalulintas sekitarnya

2. Jam sibuk sore dari lalulintas sekitarnya

3. Jam puncak bangkitan lalulintas dari pembangunan baru

4. Jam puncak tarikan lalulintas dari pembangunan baru

5. Jam puncak khusus lainnya dari pembangunan baru

Tidak tertutup kemungkinan bahwa jam sibuk lalulintas sekitarnya berimpit dengan jam puncak bangkitan lalulintas, dan jam sibuk ini biasanya menjadi kondisi puncak untuk analisis dampak lalulintas . dampak lalulintas sebenarnya merupakan selisih dari bangkitan pada kondisi puncak akibat pembangunan baru dan bangkitan kondisi puncak dari penggunaan lahan.

Bangkitan lalulintas di dapat untuk setiap jam, sesuai dengan tingkat bangkitan yang diperoleh ; dalam hal ini satuannya volume kendaraan per jam (smp/jam).

\section{B. Tingkat Bangkitan Lalulintas}

Beberapa tingkat bangkitan lalulintas yang dapat dipakai mengacu pada hasil kajian antaranya : perkantoran, hotel, pemukiman, apartemen. Dan tingkat bangkitan lalulintas untuk lokasi perumahan hasil kajian Danayasa City tertera pada tabel sebagai berikut : 
Tabel 1Tingkat bangkitan lalulintas (pemukiman)

\begin{tabular}{|c|c|c|c|c|}
\hline \multirow{2}{*}{ Bangkitan } & \multicolumn{4}{|c|}{ perjalanan / keluarga } \\
\cline { 2 - 5 } & \multicolumn{2}{|c|}{ perumahan mewah } & \multicolumn{2}{c|}{ perumahan tidak mewah } \\
\cline { 2 - 5 } & $07.00-08.00$ & $16.00-17.00$ & $\mathbf{0 7 . 0 0 - 0 8 . 0 0}$ & $\mathbf{1 6 . 0 0 - 1 7 . 0 0}$ \\
\hline \multirow{2}{*}{ Masuk } & 0,06 & 0,25 & 0,03 & 0,013 \\
Keluar & 0,25 & 0,12 & 0,013 & 0,06 \\
\hline
\end{tabular}

Sumber : LP-ITB (1996)

\section{Sebaran bangkitan lalulintas}

Setelah bangkitan lalulintas di dapat per jam, barulah dilakukan sebaran bangkitan lalulintas pada setiap pintu keluar/masuk yang ada. Pergerakan internal - pergerakan bangkitan dan tarikan dari tata guna lahan itu mengakibatkan pergerakan yang kebutuhan perjalannannya telah tersedia di kawasan tersebut.

Pergerakan ini dapat dari hasil penurunan angka pergerakan itu diperkirakan sebesar 25\% dari total pergerakan yang sebenarnya terjadi.

\section{Model Bangkitan Pergerakan}

Tujuan dasar bangkitan pergerakan adalah menghasilkan model hubungan yang mengaitkan tata guna lahan dengan jumlah pergerakan jumlah yang menuju ke suatu zona atau jumlah pergerakan yang meninggalkan suatu zona. Hasil keluaran dari perhitungan bangkitan dan tarikan lalu lintas berupa jumlah kendaraan, orang atau angkutan barang per satuan waktu, misalkan kendaraan per jam. Tujuan akhir dari tahap pemodelan bangkitan pergerakan adalah untuk menaksir bangkitan dan tarikan pergerakan pada masa sekarang, yang akan berguna untuk meramalkan pergerakan dimasa mendatang.

Untuk memodelkan besarnya pergerakan yang terjadi biasannya digunakan data berbasis zona seperti tata guna lahan, pemilikan kendaraan, populasi, jumlah pekerja, Kepadatan penduduk, pendapatan, dan juga moda transportasi yang digunakan terdapat beberapa metode untuk 
memperkirakan bangkitan peregerakan antara lain dengan menggunakan analisa regresi dan analisa klarifikasi silang.

\section{Jenis Tata Guna Lahan}

Jenis tata guna lahan yang berbeda (pemukiman, pendidikan, dan Komersial) mempunyai ciri bangkitan lalu lintas yang berbeda : jumlah arus lalu lintas, jenis lalu lintas (pejalan kaki,truk,mobil,motor,dll) dan lalu lintas pada waktu tertentu (kantor menghasilkan arus lalu lintas pagi dan sore, sedangkan pertokoan menghasilkan arus lalu lintas sepanjang hari)

Jumlah dan jenis lalu lintas yang dihasilkan oleh setiap tata guna lahan merupakan hasil dari fungsi parameter sosial dan ekonomi. Hal ini (Black,1978) mengemukakan contoh di Amerika Serikat sebagai berikut :

1. 1 ha perumahan menghasilkan $60-70$ pergerakan kendaraan per minggu;

2. 1 ha perkantoran menghasilkan 700 pergerakan kendaraan per hari ; dan

3. 1 ha tempat parkir umum menghasilkan 12 pergerakan kendaraan per hari;

\section{E. Aktivitas Tata Guna Lahan}

Semakin tinggi tingkat penggunaan sebidang tanah, semakin tinggi pergerakan arus lalu lintas yang dihasilkan. Salah satu ukuran intensitas tata guna lahan (sebidang tanah) adalah kepadatannya. Bangkitan lalu lintas dari suatu daerah pemukiman yang mempunyai tingkat kepadatan berbeda di inggris (Black,1978) 